\title{
Correction to: Chlorinated and brominated organic pollutants in shellfish from the Yellow Sea and East China Sea
}

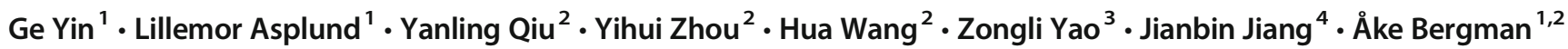

Published online: 5August 2019

(C) The Author(s) 2019

\section{Correction to: Environ Sci Pollut Res (2015) 22:1713-1722 https://doi.org/10.1007/s11356-014-3198-8}

The article Chlorinated and brominated organic pollutants in shellfish from the Yellow Sea and East China Sea, written by Ge Yin, Lillemor Asplund, Yanling Qiu, Yihui Zhou, Hua Wang, Zongli Yao, Jianbin Jiang and Åke Bergman, was originally published electronically on the publisher's internet portal (currently SpringerLink) on 25 June 2014 without open access.

With the author(s)' decision to opt for Open Choice the copyright of the article changed on July 2019 to OThe Author(s) 2019 and the article is forthwith distributed under the terms of the Creative Commons Attribution 4.0 International License (http://creativecommons.org/licenses/by/4.0/), which permits use, duplication, adaptation, distribution and reproduction in any medium or format, as long as you give appropriate credit to the original author(s) and the source, provide a link to the Creative Commons license and indicate if changes were made.

Open Access This article is distributed under the terms of the Creative Commons Attribution 4.0 International License (http:// creativecommons.org/licenses/by/4.0/), which permits unrestricted use, distribution, and reproduction in any medium, provided you give appropriate credit to the original author(s) and the source, provide a link to the Creative Commons license, and indicate if changes were made.

Pulisher's note Springer Nature remains neutral with regard to jurisdictional claims in published maps and institutional affiliations

The online version of the original article can be found at https://doi.org/ $10.1007 / \mathrm{s} 11356-014-3198-8$

Ge Yin

ge.yin@mmk.su.se

1 Department of Materials and Environmental Chemistry, Stockholm University, 10691 Stockholm, Sweden

2 College of Environmental Science and Engineering, Tongji University, 200092 Shanghai, China

3 East China Sea Fisheries Research Institute, Chinese Academy of Fishery Sciences, 200090 Shanghai, China

4 Tongzhou Fisheries Technical Instruction Station of Nantong, 226300 Nantong, China 